\title{
Challenges and opportunities to scale up sustainable finance after the COVID-19 crisis: lessons and promising innovations from science and practice
}

\author{
Simone Quatrini ${ }^{1}$ \\ ${ }^{1}$ Eidgenossische Technische Hochschule Zurich
}

April 28, 2020

\begin{abstract}
Over the past few years, the international community adopted important policy frameworks to foster an inclusive green economy that acknowledges the value of ecosystem services, protects natural resources and promotes a sustainable future. Without finance in the tune of trillions of dollars annually, all these objectives and commitments will remain on paper. As the COVID19 pandemic deflected the attention of governments away from long-term sustainability objectives and imposed unparalleled injections of public capital to rescue national economies, the survival of global environmental and socio-economic sustainability priorities becomes more than ever dependent on the private sector. This requires a progressive rather than defensive financial system. One that reinvigorates the sustainability momentum established by the Sustainable Development Goals (SDG), by supporting the best examples of responsible behaviour, circularity, and solidarity that emerged during the health crisis. In turn, this demands a profound rethinking of sustainable finance instruments, practices, metrics and tools in use prior to the crisis, which were clearly failing in their ability to mobilize sufficient public and private capital to accomplish the sustainability transition and convince stakeholders of results achieved. This article provides a review of some of these decision-support tools, focussing in particular on instruments of non-financial disclosure. Its main objective is to highlight key issues and gaps in sustainability assessment practice, which help explain the sustainable finance challenges and failures observed prior to the COVID-19 crisis, while pinpointing some promising examples of novel approaches that could enable a system update \& reboot and revive sustainable development ambitions
\end{abstract}

\section{Hosted file}

Manuscript_Main text_No tables_No figures.docx available at https://authorea.com/users/316113/ articles/446328-challenges-and-opportunities-to-scale-up-sustainable-finance-after-the-covid19-crisis-lessons-and-promising-innovations-from-science-and-practice

\section{Hosted file}

Tables.docx available at https://authorea.com/users/316113/articles/446328-challenges-and-opportunitiesto-scale-up-sustainable-finance-after-the-covid-19-crisis-lessons-and-promising-innovationsfrom-science-and-practice

\section{Hosted file}

Figures.docx available at https ://authorea.com/users/316113/articles/446328-challenges-and-opportunitiesto-scale-up-sustainable-finance-after-the-covid-19-crisis-lessons-and-promising-innovationsfrom-science-and-practice 


\section{Hosted file}

References.docx available at https://authorea.com/users/316113/articles/446328-challenges-andopportunities-to-scale-up-sustainable-finance-after-the-covid-19-crisis-lessons-and-promisinginnovations-from-science-and-practice 